\title{
1 Stability of 5-methyltetrahydrofolate in fortified apple and carrot purées
}

2 Anna-Lena Herbig ${ }^{1}$, Nicolas Delchier ${ }^{2}$, Lisa Striegel ${ }^{2}$, Michael Rychlik ${ }^{2}$, Catherine M.G.C. Renard ${ }^{1} *$

$3{ }^{1}$ UMR408 SQPOV «Sécurité et Qualité des Produits d'Origine Végétale», INRA, Université

4 d'Avignon et des Pays du Vaucluse, F-84000 Avignon, France.

$5{ }^{2}$ Chair of Analytical Food Chemistry, Technische Universität München, Alte Akademie 10, D-85354

6 Freising, Germany

$7 \quad *$ Corresponding Author: catherine.renard@inra.fr

$8 \quad$ anna-lena.herbig@mail.de

9 nicolas.delchier@gmail.com

10 lisa.striegel@tum.de

11 michael.rychlik@tum.de

12 Catherine M.G.C. Renard

13 INRA - UMR 408 SQPOV

14 Domaine St Paul, Site Agroparc

$15 \quad$ F-84914 Avignon Cedex 09

16 FRANCE

17 Phone: $+33(0) 4.32 .72 .25 .28$

18 Fax: $+33(0) 4.32 .72 .24 .92$ 
5-Methyltetrahydrofolate, the naturally abundant folate vitamer, has been proposed as an alternative to

folic acid for fortification. However, it is less stable than folic acid. In a formate buffer ( $\mathrm{pH}$ 3.5), folic acid was entirely preserved after heating the solution for $3 \mathrm{~h}$ at $80{ }^{\circ} \mathrm{C}$. In contrast, 5methyltetrahydrofolate was completely degraded in less than 15 minutes. As in the buffer, 5methyltetrahydrofolate in apple or carrot purées degraded rapidly without the addition of ascorbic acid. By adding ascorbic acid, the stability could be increased, but the chosen amount was crucial. An excess of vitamin C compared to 5-methyltetrahydrofolate was not always sufficient for the complete protection of 5-methyltetrahydrofolate during $3 \mathrm{~h}$ at $80^{\circ} \mathrm{C}$. Only by adding $2840 \mu \mathrm{mol} / \mathrm{kg}$ of ascorbic acid (equivalent to $500 \mathrm{mg} / \mathrm{kg}$ ), 5-methyltetrahydrofolate seemed to remain stable. Degradation started after approximately 60 minutes when $570 \mu \mathrm{mol} / \mathrm{kg}$ of ascorbic acid (equivalent to $100 \mathrm{mg} / \mathrm{kg}$ ) were added; after 120 minutes with $1420 \mu \mathrm{mol} / \mathrm{kg}$ (equivalent to $250 \mathrm{mg} / \mathrm{kg}$ ). In addition, a temperature decrease to $70{ }^{\circ} \mathrm{C}$ or $60{ }^{\circ} \mathrm{C}$ did not increase the stability of 5-methyltetrahydrofolate.

Keywords: folate, fortification, food matrix, degradation, impacts

\section{Introduction}

Folic acid fortification is linked to a reduced risk of neural tube defects in newborns-and thus became mandatory in the United States and other countries for cereal products (Eichholzer, Tonz, \& Zimmermann, 2006; Grosse \& Collins, 2007). In addition, the insufficient intake of folates is associated with a higher colorectal cancer risk (Kim, 2003). Folic acid, a synthetic vitamer, is predominantly used for fortification and is transformed in the body into naturally occurring forms. When ingested in high doses, however, it also circulates in its unmetabolised form (Smith, Kim, \& Refsum, 2008). Furthermore, folic acid fortification in excess (>1000 $\mu \mathrm{g} /$ day) can mask the vitamin $\mathrm{B}_{12}$ deficiency. Thus 5-methyltetrahydrofolate is naturally abundant form in the body, it has been proposed as an alternative fortificant (Pietrzik, Bailey, \& Shane, 2010; Scaglione \& Panzavolta, 2014). 
Concerning its chemical structure, 5-methyltetrahydrofolate differs from folic acid by being reduced in positions $\mathrm{N}(5), \mathrm{C}(6)$ and $\mathrm{C}(7)$, and $\mathrm{N}(8)$, while hydrogen in position $\mathrm{N}(10)$ is substituted by a methyl group (Delchier, Herbig, Rychlik, \& Renard, 2016; Scott, Rebeille, \& Fletcher, 2000). This structural difference has an enormous effect on stability. Compared to folic acid, 5-methyltetrahydrofolate is highly susceptible to oxidation. In the absence of oxygen, 5-methyltetrahydrofolate is completely stable (Delchier et al., 2014). The stability of 5-methyltetrahydrofolate under aerobic conditions decreases with rising temperatures (Indrawati et al., 2004; Nguyen, Indrawati, \& Hendrickx, 2003; Oey, Verlinde, Hendrickx, \& Van Loey, 2006) and depends on pH. It is more stable in a neutral rather than in an acidic medium (Indrawati et al., 2004; Liu et al., 2012). At the same pH, its stability depends additionally on the buffer solution used (Indrawati et al., 2004; Paine-Wilson \& Chen, 1979).

The degradation of 5-methyltetrahydrofolate is accelerated by fructose but not by glucose (Verlinde et al., 2010). The impact is independent of the sugar concentration in the range from $1.6 \mathrm{mmol} / \mathrm{L}$ to 1.5 $\mathrm{mol} / \mathrm{L}$ and is linked to a new product that is formed by the glycation of the exocyclic amino group of 5-methyltetrahydrofolate (Figure 1). This product is formed along with the three degradation products that are also generated in the absence of fructose (Figure 1). The acceleration of degradation by a fructose is counteracted by ascorbic acid, probably by reduction of the first oxidation product, 5methyl-7,8-dihydrofolate.

Liu et al. (2012) and Oey et al. (2006) reported that ascorbic acid decreases the degradation of 5methyltetrahydrofolate . Oey et al. (2006) related the concentration of ascorbic acid necessary to protect 5-methyltetrahydrofolate to the initial oxygen concentration. The concentration of ascorbic acid that led to a complete protection between $50{ }^{\circ} \mathrm{C}$ and $170{ }^{\circ} \mathrm{C}$ for 15 minutes was claimed to be twice as high as the molar initial oxygen concentration (Liu et al., 2012; Oey et al., 2006). However, the relationship can be supposed to be valid only in the analysed time range as ascorbic acid is also susceptible to degradation and thus, the protection effect will be lost once the ascorbic acid is degraded.

Almost all groups who studied the stability of 5-methyltetrahydrofolate, used model solutions: PaineWilson and Chen (1979) worked with McIlvaine, $\mathrm{HCl} / \mathrm{KCl}$ and citrate buffers; Nguyen et al. (2003) 
with phosphate buffer; Oey et al. (2006) with phosphate buffer; Verlinde et al. (2010) with water and Liu et al. (2012) with HEPES/CHES buffer. Mnkeni and Beveridge (1983) reported a faster degradation of 5-methyltetrahydrofolate in tomato and apple juices than in a citrate buffer. When comparing buffers and different foods, Indrawati et al. (2004) observed but did not explain different behaviours. Delchier et al. (2014) used spinach and green bean purées but only modulated oxygen. Therefore, the mutual influence of factors ( $\mathrm{pH}$, oxygen, ascorbic acid, sugars) with the complex composition and physico-chemistry of foods has hardly been taken into account. In particular, dissolved oxygen in real food products may also be consumed by other oxidisable compounds, which may change the relationship. For example, $500 \mathrm{mg} / \mathrm{kg}$ of ascorbic acid increase the stability of 5methyltetrahydrofolate in carrot juice but not in asparagus when heat-treated for 40 minutes at $120{ }^{\circ} \mathrm{C}$ (Indrawati et al., 2004). The stability difference of 5-methyltetrahydrofolate in skim milk and soy milk has been linked to the different antioxidant capacities of the two food systems (Liu et al., 2012).

For the present study, apple purée and carrot purée were used as fortified food matrices since they are usually less heat-treated than cereal products and are well appreciated all over Europe. They are representative fruit and vegetable foods with different $\mathrm{pHs}$, fructose contents, and antioxidants. The aim was to find suitable reheating conditions in the temperature range of $60-80{ }^{\circ} \mathrm{C}$ to impart high stability to 5-methyltetrahydrofolate in apple purée and carrot purée.

\section{Material and methods}

\subsection{Chemicals}

Formic acid, 2-(N-morpholino)-ethanesulfonic acid (MES) hydrate, 2,2'-Bipyridyl, ascorbic acid, trichloroacetic acid, DL-dithiothreitol, $\mathrm{Na}_{2} \mathrm{HPO}_{4}, \mathrm{NaH}_{2} \mathrm{PO}_{4} \cdot \mathrm{H}_{2} \mathrm{O}, \mathrm{N}$-Ethylmaleimide, folic acid and citric acid monohydrate were purchased from Sigma Aldrich (Steinheim, Germany), and acetonitrile, methanol, ortho-phosphoric acid (85\%), iron (III) chloride hexahydrate and ascorbic acid from VWR (Darmstadt, Germany). Applichem GmbH (Darmstadt, Germany) provided 2,3-Dihydroxybutan-1,4dithiol; and $\left[{ }^{13} \mathrm{C}_{5}\right]-5$-methyltetrahydrofolate, $\left[{ }^{13} \mathrm{C}_{5}\right]$-folic acid, disodium hydrogen phosphate, 
potassium dihydrogen phosphate, sodium acetate trihydrate and acetic acid were supplied by Merck (Darmstadt, Germany). Sodium hydroxide and sodium chloride were obtained from J.T. Baker (Deventer, the Netherlands) and ethanol from Fisher Scientific (Fair Lawn, NJ, USA). 5Methyltetrahydrofolate was purchased from Schircks (Jona, Switzerland).

\subsection{Fortification and thermal treatment}

The formate buffer was attained by diluting formic acid $(10 \mathrm{~mL} / \mathrm{L})$ with distilled water and adding sodium hydroxide to the solution until a $\mathrm{pH}$ of 3.5. Apple purée (brand: ALNATURA) and carrot purée (brand: HIPP) without additives were purchased at a supermarket in Freising, Germany. In order to attain a concentration of $4.0 \mu \mathrm{mol} / \mathrm{kg}$ of 5 -methyltetrahydrofolate and folic acid, the dilution steps were carried out as follows: The 5-methyltetrahydrofolate and folic acid were pre-dissolved in a phosphate buffer ( $\mathrm{pH}$ 7.0) and diluted with distilled water to a volume of $100 \mathrm{~mL}$; Subsequently, 10 $\mathrm{mL}$ of this solution were added to $40 \mathrm{~g}$ of apple purée and carrot purée and thoroughly vortexed. Homogeneity was tested by comparing the recovery amount in two aliquots of two independently prepared fortification mixtures. Amber glass vials $(4 \mathrm{~mL})$ were filled with $2 \mathrm{~mL}$ of a formate buffer solution containing $4.0 \mu \mathrm{mol} / \mathrm{kg}$ of 5-methyltetrahydrofolate, or up to the corresponding height in the case of fortified apple and carrot purées, and closed with screw caps. Thermal treatments were carried out in a stirred silicon oil bath. Temperatures at the bottom and in the middle were verified and showed a homogenous temperature distribution over time. After taking the tubes out of the silicon oil bath, the tubes were immediately deep-frozen $\left(\leq-18{ }^{\circ} \mathrm{C}\right)$. Before analysis, glass vials were put in a water bath for rapid thawing. The first point of every time curve was omitted from the heat treatment.

\subsection{Folate analysis}

The stable isotope dilution assay of Ringling and Rychlik (2013) was employed with the modification that only the vitamer 5-methyltetrahydrofolate was analysed and ${ }^{13} \mathrm{C}$ - instead of ${ }^{2} \mathrm{H}$-labelled standards were taken for quantification. Shortly after an equilibration of the isotopic marked internal standards with the sample, the extraction of folates followed. Before analysis by HPLC-MS/MS, the samples were purified. 
Instrumental conditions were identical. A HyperClone Reversed Phase Column C18 (Phenomenex, Aschaffenburg, Germany) was used for separations. Values were first calculated as calcium salt. The percental aberration of a fixed standard concentration of $200 \mu \mathrm{g} / 100 \mathrm{~g}$ was then calculated and was on average $7 \pm 7 \%$. Each point of a time curve was subsequently corrected by the percental aberration of the first value to the standard concentration, to avoid parallelism of kinetics. The values were then transferred to their actual 5-methyltetrahydrofolate content by taking into consideration the calcium proportion, and converted to their molar concentration by respecting a molar mass of $459 \mathrm{~g} / \mathrm{mol}$.

\subsection{Ascorbic acid analysis}

Ascorbic acid quantification was carried out by means of the colorimetric method of Stevens, Buret, Garchery, Carretero, and Causse (2006). Modifications were the following: approximately $500 \mathrm{mg}$ of the food sample were taken for extraction, and absorption was measured at $525 \mathrm{~nm}$ on a spectrophotometer (Safas Xenius, Monaco).

\section{Results and discussion}

\subsection{Natural folate concentration, extraction yield and test of homogeneity}

Apples and carrots are food matrices that contain inherently low amounts of folates. Raw apples do not contain any measurable folates amounts and raw carrots only contain $19 \mu \mathrm{g} / 100 \mathrm{~g}$ of folates (USDA, 2016). The amount of 5-methyltetrahydrofolate monoglutamate in the purchased apple purée was under the limit of quantification for the analytical method, which is $0.22 \mu \mathrm{g} / 100 \mathrm{~g}$ (Ringling \& Rychlik, 2013). The concentration of 5-methyltetrahydrofolate in carrot purée was $2.5 \pm 0.1 \mu \mathrm{g} / 100 \mathrm{~g}$

141 which was in the range listed on the USDA platform for raw carrot (19 $\mu \mathrm{g} / 100 \mathrm{~g}$, USDA, 2018).

142 Natural amounts of 5-methyltetrahydrofolate in both matrices were thus negligible compared to the 143 target fortification level of $185 \mu \mathrm{g} / 100 \mathrm{~g}$ corresponding to $4.0 \mu \mathrm{mol} / \mathrm{kg}$. Folic acid is a synthetic, not144 naturally-occurring vitamer, and is thus not present in apple and carrots. 
In order to verify the homogeneity of fortification preparations, the apple purée was supplemented with folic acid. Recovery rates accounted to $107 \pm 5 \%$ and $109 \pm 1 \%$, which were determined by analysing two aliquots of two independently prepared fortification mixtures. Extraction was thus quantitative and homogeneity was acceptable, indicated by low standard deviations.

\subsection{Stability in buffer solution and apple purée}

150

The stability of the folic acid and 5-methyltetrahydrofolate was first evaluated in a formate buffer (10 $\mathrm{mL} / \mathrm{L}, \mathrm{pH} 3.5$ ) heated at $80{ }^{\circ} \mathrm{C}$. The daily folate amount recommended by the European Food Safety Authority (EFSA) depends on the origin of the folate, as natural folates are less bioavailable than folic acid (EFSA, 2014). A dietary folate equivalent (DFE) is usually applied to convert folic acid amounts to the concentration that would be ingested if natural folates were absorbed. One $\mu \mathrm{g}$ of DFE is defined as $1 \mu \mathrm{g}$ food folate, which in turn corresponds to $0.6 \mu \mathrm{g}$ of folic acid from fortified food. This conversion factor was considered when preparations were carried out and it results in differing initial values depending on the vitamer used (Figure 2). Consistent with literature results (Delchier et al., 2016; O'Broin, Temperley, Brown, \& Scott, 1975; Paine-Wilson \& Chen, 1979), folic acid was more stable than 5-methyltetrahydrofolate (Figure 2A). Folic acid dissolved in a formate buffer was completely stable at $80{ }^{\circ} \mathrm{C}$ for the duration of 180 minutes while in turn 5-methyltetrahydrofolate degraded entirely within 15 minutes. The stability of folates depends on ions (Indrawati et al., 2004; Paine-Wilson \& Chen, 1979); hence direct comparison of degradation rates with literature results is not possible as other buffer solutions were used. However, the degradation of 5-methyltetrahydrofolate occurred within the same time range as previously reported, registering a complete loss within some minutes (O'Broin et al., 1975; Paine-Wilson \& Chen, 1979).

According to literature, the stability of 5-methyltetrahydrofolate for 15 minutes up to $170{ }^{\circ} \mathrm{C}$ can be obtained by adding ascorbic acid (Oey et al., 2006). In the present study, the addition of $2840 \mu \mathrm{mol} / \mathrm{kg}$ of ascorbic acid induced complete stability of 5-methyltetrahydrofolate in the formate buffer for three hours at $80{ }^{\circ} \mathrm{C}$ (Figure 2A). The apple puree contains fructose, which is known to accelerate the degradation of folates (Verlinde et al., 2010), but also polyphenols that may potentially exhibit a protective effect as a result of their anti-oxidative properties. Therefore, the stability of folic acid and 
5-methyltetrahydrofolate was also assessed in apple purée (Figure 2B). As in the formate buffer, folic acid was completely stable over the investigated time range and 5-methyltetrahydrofolate degraded rapidly (Figure 2B). Mnkeni and Beveridge (1983) found that 5-methyltetrahydrofolate is also fairly unstable in apple juice. When $2840 \mu \mathrm{mol} / \mathrm{kg}$ of ascorbic acid were added, the complete stability of 5methyltetrahydrofolate was also attained in the apple puree. Naturally present polyphenols in the apple purée did not lead to the same stability as the addition of $2840 \mu \mathrm{mol} / \mathrm{kg}$ of ascorbic acid. Ascorbic acid completely protected the 5-methyltetrahydrofolate in the apple purée even in the presence of a high amount of fructose. This is coherent with the result of Verlinde et al. (2010), who studied the stability of 5-methyltetrahydrofolate $(0.04 \mathrm{mmol} / \mathrm{L})$ in the presence of fructose $(0.04 \mathrm{mmol} / \mathrm{L})$ and ascorbic $\operatorname{acid}(1.13 \mathrm{mmol} / \mathrm{L})$ in a model solution which was heated for 45 minutes at $100{ }^{\circ} \mathrm{C}$.

Thus, 5-methyltetrahydrofolate, in the presence of $2840 \mu \mathrm{mol} / \mathrm{kg}$ of ascorbic acid is equally as suitable for fortification as folic acid. Both vitamers withstood long periods of heating that can be encountered when food is reheated and kept warm for several hours. Until now, flour products have been exclusively chosen for mandatory folic acid fortification in the United States. However, folic acid, a fairly stable folate vitamer, is lost during the bread baking process (Gujska \& Majewska, 2005).

Neither folic acid nor 5-methyltetrahydrofolate in the presence of $2840 \mu \mathrm{mol} / \mathrm{kg}$ of ascorbic acid were lost in the apple puree under the reported conditions. Thus, this study suggests that with regard to stability, apple purée exhibits an advantageous fortification matrix compared to flour that is baked into bread.

\subsection{Concentration effect of ascorbic acid on the stability of 5-methyltetrahydrofolate} tested in apple and carrot purées

The amount of ascorbic acid $(2840 \mu \mathrm{mol} / \mathrm{kg})$ used for the assessment above was added in excess when compared to the content of 5-methyltetrahydrofolate $(4.0 \mu \mathrm{mol} / \mathrm{kg})$. It was also much higher than the concentration of dissolved oxygen, which was not measured but is of $258 \mu \mathrm{mol} / \mathrm{kg}$ in water at $25{ }^{\circ} \mathrm{C}$ and is probably even lower under the studied conditions, given the matrices and temperatures used (Penicaud, Peyron, Gontard, \& Guillard, 2012). In the next phase, lower amounts of ascorbic acid were added to the apple purée so as to verify if stability was still maintained. However, the addition of 
neither $570 \mu \mathrm{mol} / \mathrm{kg}$ nor $1420 \mu \mathrm{mol} / \mathrm{kg}$ led to the absolute stability of 5-methyltetrahydrofolate within the investigated time range (Figure 3A). When adding $570 \mu \mathrm{mol} / \mathrm{kg}$ of ascorbic acid, degradation started within 60 minutes and amounted to $30 \pm 1 \%$ after 180 minutes and in the case of 1420 $\mu \mathrm{mol} / \mathrm{kg}$, it initiated within 120 minutes and reached $17 \pm 3 \%$ after 180 minutes. However, once degradation started, the depletion pace for both ascorbic acid concentrations was still slower than when no vitamin $\mathrm{C}$ was added. In order to examine whether the loss of complete preservation of 5methyltetrahydrofolate was linked to a loss of ascorbic acid, the concentration of the latter was followed over the time period analysed (Figure 3B). However, the amounts of ascorbic acid still present when the degradation of 5-methyltetrahydrofolate started were quite high.

Oey et al. (2006) reported that even low amounts of ascorbic acid $(284 \mu \mathrm{mol} / \mathrm{L})$ are sufficient to completely protect 5 -methyltetrahydrofolate $(4 \mu \mathrm{mol} / \mathrm{L})$ at $80{ }^{\circ} \mathrm{C}$. From these results, it can be concluded that besides the amount of ascorbic acid present in the medium, another time-dependent factor seems to crucially influence the stability of 5-methyltetrahydrofolate. It might be that dissolved oxygen is involved in this phenomenon. Dissolved oxygen was consumed within one hour in apple purée heated at $80^{\circ} \mathrm{C}$ under the conditions of Herbig, Maingonnat, and Renard (2017), but this was not tested in the present work due to the difficult access of the oxygen sensor to the medium in the experimental set-up. The degradation of 5-methyltetrahydrofolate does not proceed when the medium is deprived of oxygen before the heat treatment (Delchier et al., 2014). It may also be that the generation of reactive oxygen species might as well be implicated in this phenomenon. Boatright (2016) measured up to $32.5 \mu \mathrm{mol} / \mathrm{L}$ of hydrogen peroxide during the oxidation of $100 \mu \mathrm{mol} / \mathrm{L}$ of ascorbic acid. The formation of hydrogen peroxide and other reactive oxygen species during the oxidation of ascorbic acid and possibly also other components in the apple purée medium, might explain the time-limited protective effect of ascorbic acid. A longer protection with increasing amounts of ascorbic acid is consistent with the assumption of reactive oxygen species being involved, as the probability rises that reactive oxygen species encounter an ascorbic acid molecule before a 5methyltetrahydrofolate one. 
Another explanation might also be an implication of sugar derivatives. In model solutions, ascorbic acid protects 5-methyltetrahydrofolate in the presence of fructose $\left(100{ }^{\circ} \mathrm{C}, 45\right.$ minutes) by reducing 5 methyldihydrofolate, the first oxidation product (Figure 1) (Verlinde et al., 2010). In an apple purée, the protective effect might, however, be counteracted by an accumulation of sugar degradation products in the course of time and consequently explain the shifted degradation initiation of 5methyltetrahydrofolate. In addition, since some ascorbic acid degradation products, namely dehydroascorbic acid and 2,3-diketogulonic acid, are also dicarbonyls that are even more reactive Maillard precursors than sugars, they might participate in the shifted degradation beginning (Ortwerth \& Olesen, 1988; Reihl, Lederer, \& Schwack, 2004; Roig, Bello, Rivera, \& Kennedy, 1999; Slight, Feather, \& Ortwerth, 1990).

In future studies, it might therefore be interesting to study the combined effect of the amount of oxygen in the headspace, dissolved oxygen, the appearance of reactive oxygen species, sugar derivatives and ascorbic acid derivatives, in order to understand the interactions more profoundly. Until these interactions are understood in detail, degradation kinetics cannot be extrapolated to other experimental set-ups.

As the composition of the food matrix may potentially influence the stability of 5methyltetrahydrofolate, the latter was subsequently supplemented to carrot purée so as to verify possible stability changes. As with the apple purée, when no ascorbic acid was added, the 5methyltetrahydrofolate was very fragile and degraded rapidly. Its stability in carrot purée in the presence of $570 \mu \mathrm{mol} / \mathrm{kg}$ and $2840 \mu \mathrm{mol} / \mathrm{kg}$ of ascorbic acid was not different from that of the apple puree when the same amount of ascorbic acid was added (Figure 3C). Stability was attained with the presence of $2840 \mu \mathrm{mol} / \mathrm{kg}$ of ascorbic acid but not when only $570 \mu \mathrm{mol} / \mathrm{kg}$ were used for fortification. Coherently, Mnkeni and Beveridge (1983), who studied the stability of fortified folic acid in apple and tomato juices $\left(100-140{ }^{\circ} \mathrm{C}\right)$, did not observe any difference between degradation paces in the two studied food media despite their different compositions. In accordance with results obtained for the apple purée and with those of Indrawati et al. (2004), who worked with carrot juice (500 mg/kg of 
ascorbic acid) heated at $120{ }^{\circ} \mathrm{C}$ for 40 minutes, the presence of ascorbic acid in carrot purée was linked to a high stability of 5-methyltetrahydrofolate.

\subsection{Temperature effect $\left(60-80^{\circ} \mathrm{C}\right)$}

254

Temperature diminishes the stability of 5-methyltetrahydrofolate in a model solution according to the Arrhenius equation (Indrawati et al., 2004; Nguyen et al., 2003; Oey et al., 2006). However, the extent depends on the $\mathrm{pH}$ used and on the buffer ions (Indrawati et al., 2004; Paine-Wilson \& Chen, 1979). It was hypothesised that stability for $3 \mathrm{~h}$ could be reached in apple puree with only $570 \mu \mathrm{mol} / \mathrm{kg}$ of ascorbic acid by decreasing temperature. However, when the temperature was decreased from $80{ }^{\circ} \mathrm{C}$ to $70{ }^{\circ} \mathrm{C}$ or to $60{ }^{\circ} \mathrm{C}$, the stability did not increase at the same time (Figure 4). Apparently, the supply of energy was not the limiting factor for the degradation pace in this temperature range. Indrawati et al. (2004) studied the impact of temperature on the stability of 5-methyltetrahydrofolate in orange juice, kiwi purée, carrot juice and asparagus. In the mentioned study, orange juice and kiwi purée contained $500 \mathrm{mg} / \mathrm{kg}$ of ascorbic acid i.e. $2840 \mu \mathrm{mol} / \mathrm{kg}$, and carrot juice and asparagus contained $100 \mathrm{mg} / \mathrm{kg}$ of ascorbic acid, corresponding to $570 \mu \mathrm{mol} / \mathrm{kg}$. Consistent with the results of this study, they observed no marked impact between the amount that degraded at $70{ }^{\circ} \mathrm{C}$ or at $80{ }^{\circ} \mathrm{C}$ in the different food matrices.

\section{Conclusion}

The heat susceptibility of 5-methyltetrahydrofolate was confirmed in apple and carrot purées. Polyphenols and carotenoids that could, due to their anti-oxidative properties, potentially enhance the stability of 5-methyltetrahydrofolate are far from being as effective as the addition of vitamin C. Stability can only be obtained in the presence of vitamin C. The vitamin C amount which is necessary to entirely protect 5-methyltetrahydrofolate depends on the intended duration of the heat treatment. The length of time of complete stability can be prolonged by increasing the vitamin $\mathrm{C}$ concentration. The molar vitamin $\mathrm{C}$ concentration is not directly related to the concentration of 5methyltetrahydrofolate. Even if the amount of ascorbic acid is still in excess considering the amount of 
5-methyltetrahydrofolate or dissolved oxygen, degradation starts in the course of time. A timedependent factor seems to intervene. Decreasing temperature in the range of $60-80{ }^{\circ} \mathrm{C}$ does not have a marked impact on the stability of 5-methyltetrahydrofolate. Thus, by heating purees at $80{ }^{\circ} \mathrm{C}$, the risk of microbial growth can be decreased while the same nutritional value is maintained as if heated at 60 ${ }^{\circ} \mathrm{C}$. Apple purée and carrot purée in the presence of an adequate amount of vitamin $\mathrm{C}$ are thus suitable food matrices for folate fortification.

\section{Acknowledgement}

283

This project has received funding from the European Union's Seventh Framewok Programme OPTIFEL for research, technological development and demonstration under grant agreement $\mathrm{n}^{\circ} 311754$. 
300

301

302

303

304

305

306

307

308

309

Fig. 3. Impact of the concentration of ascorbic acid on the stability of 5- $\mathrm{CH}_{3}-\mathrm{H}_{4}$ folate in apple and carrot purées heated at $80^{\circ} \mathrm{C}$.

A: Stability of 5- $\mathrm{CH}_{3}-\mathrm{H}_{4}$ folate in apple purée containing an initial ascorbic acid concentration of $\nabla 570 \mu \mathrm{mol} / \mathrm{kg}$, 口 $1420 \mu \mathrm{mol} / \mathrm{kg}$ or $\bullet 2840 \mu \mathrm{mol} / \mathrm{kg}$.

B: Ascorbic acid content in apple purée during heat treatment as a function of the initial concentration. Ascorbic acid initial concentration: $\$ 570 \mu \mathrm{mol} / \mathrm{kg}$ vs. $1420 \mu \mathrm{mol} / \mathrm{kg}$ and $\bullet 2840 \mu \mathrm{mol} / \mathrm{kg}$.

C: Stability of $5-\mathrm{CH}_{3}-\mathrm{H}_{4}$ folate in carrot purée after an ascorbic acid addition of $* 570 \mu \mathrm{mol} / \mathrm{kg}$ or $。$ $2840 \mu \mathrm{mol} / \mathrm{kg}$.

Fig. 4. Impact of temperature on the degradation of $5-\mathrm{CH}_{3}-\mathrm{H}_{4}$ folate.

$5-\mathrm{CH}_{3}-\mathrm{H}_{4}$ folate in apple purée containing $570 \mu \mathrm{mol} / \mathrm{kg}$ of ascorbic acid

during a heat treatment at $\nabla 60^{\circ} \mathrm{C}$, $\square 70{ }^{\circ} \mathrm{C}$, and $\bullet 80^{\circ} \mathrm{C}$.

\section{References}

Boatright, W. L. (2016). Oxygen dependency of one electron reactions generating ascorbate radicals and hydrogen peroxide from ascorbic acid. Food Chemistry, 196, 1361-1367.

Delchier, N., Herbig, A.-L., Rychlik, M., \& Renard, C. M. G. C. (2016). Folates in fruits and vegetables: Contents, processing, and stability. Comprehensive Reviews in Food Science and Food Safety, 15(3), 506-528.

Delchier, N., Ringling, C., Cuvelier, M.-E., Courtois, F., Rychlik, M., \& Renard, C. M. G. C. (2014). Thermal degradation of folates under varying oxygen conditions. Food Chemistry, 165, 85-91.

EFSA. (2014). Draft scientific opinion on dietary reference values for folate. EFSA Journal 12(11):3893, 1-60.

Eichholzer, M., Tonz, T., \& Zimmermann, R. (2006). Folic acid: A public health challenge. Lancet, 367(9519), 1352-1361.

Grosse, S. D., \& Collins, J. S. (2007). Folic acid supplementation and neural tube defect recurrence prevention. Birth Defects Research Part A-Clinical and Molecular Teratology, 79(11), 737742.

Gujska, E., \& Majewska, K. (2005). Effect of baking process on added folic acid and endogenous folates stability in wheat and rye breads. Plant Foods for Human Nutrition, 60(2), 37-42.

Herbig, A.-L., Maingonnat, J.-F., \& Renard, C. M. G. C. (2017). Oxygen availability in model solutions and purees during heat treatment and the impact on vitamin $\mathrm{C}$ degradation. $L W T$ Food Science and Technology, 85, 493-499.

Indrawati, Arroqui, C., Messagie, I., Nguyen, M. T., Van Loey, A., \& Hendrickx, M. (2004). Comparative study on pressure and temperature stability of 5-methyltetrahydrofolic acid in model systems and in food products. Journal of Agricultural and Food Chemistry, 52(3), 485492.

Kim, Y. I. (2003). Role of folate in colon cancer development and progression. Journal of Nutrition, 133(11), 3731S-3739S.

Liu, Y., Tomiuk, S., Rozoy, E., Simard, S., Bazinet, L., Green, T., \& Kitts, D. D. (2012). Thermal oxidation studies on reduced folate, L-5-methyltetrahydrofolic acid (L-5-MTHF) and strategies for stabilization using food matrices. Journal of Food Science, 77(2), C236-C243. 
Mnkeni, A. P., \& Beveridge, T. (1983). Thermal destruction of 5-methyltetrahydrofolic acid in buffer and model food systems. Journal of Food Science, 48(2), 595-599.

Nguyen, M. T., Indrawati, \& Hendrickx, M. (2003). Model studies on the stability of folic acid and 5methyltetrahydrofolic acid degradation during thermal treatment in combination with high hydrostatic pressure. Journal of Agricultural and Food Chemistry, 51(11), 3352-3357.

O'Broin, J. D., Temperley, I. J., Brown, J. P., \& Scott, J. M. (1975). Nutritional stability of various naturally occurring monoglutamate derivatives of folic acid. American Journal of Clinical Nutrition, 28(5), 438-444.

Oey, I., Verlinde, P., Hendrickx, M., \& Van Loey, A. (2006). Temperature and pressure stability of Lascorbic acid and/or [6S] 5-methyltetrahydrofolic acid: A kinetic study. European Food Research and Technology, 223(1), 71-77.

Ortwerth, B. J., \& Olesen, P. R. (1988). Ascorbic acid induced crosslinking of lens proteins - evidence supporting a Maillard reaction. Biochimica Et Biophysica Acta, 956(1), 10-22.

Paine-Wilson, B., \& Chen, T. S. (1979). Thermal destruction of folacin - effect of $\mathrm{pH}$ and buffer ions. Journal of Food Science, 44(3), 717-722.

Penicaud, C., Peyron, S., Gontard, N., \& Guillard, V. (2012). Oxygen quantification methods and application to the determination of oxygen diffusion and solubility coefficients in food. Food Reviews International, 28(2), 113-145.

Pietrzik, K., Bailey, L., \& Shane, B. (2010). Folic acid and L-5-methyltetrahydrofolate. Clinical Pharmacokinetics, 49(8), 535-548.

Reihl, O., Lederer, M. O., \& Schwack, W. (2004). Characterization and detection of lysine-arginine cross-links derived from dehydroascorbic acid. Carbohydrate Research, 339(3), 483-491.

Ringling, C., \& Rychlik, M. (2013). Analysis of seven folates in food by LC-MS/MS to improve accuracy of total folate data. European Food Research and Technology, 236(1), 17-28.

Roig, M. G., Bello, J. F., Rivera, Z. S., \& Kennedy, J. F. (1999). Studies on the occurrence of nonenzymatic browning during storage of citrus juice. Food Research International, 32(9), 609619.

Rozoy, E., Araya-Farias, M., Simard, S., Kitts, D., Lessard, J., \& Bazinet, L. (2013). Redox properties of catechins and enriched green tea extracts effectively preserve L-5-methyltetrahydrofolate: Assessment using cyclic voltammetry analysis. Food Chemistry, 138(2-3), 1982-1991.

Scaglione, F., \& Panzavolta, G. (2014). Folate, folic acid and 5-methyltetrahydrofolate are not the same thing. Xenobiotica, 44(5), 480-488.

Scott, J., Rebeille, F., \& Fletcher, J. (2000). Folic acid and folates: The feasibility for nutritional enhancement in plant foods. Journal of the Science of Food and Agriculture, 80(7), 795-824.

Slight, S. H., Feather, M. S., \& Ortwerth, B. J. (1990). Glycation of lens proteins by the oxidation products of ascorbic acid. Biochimica Et Biophysica Acta, 1038(3), 367-374.

Smith, A. D., Kim, Y.-I., \& Refsum, H. (2008). Is folic acid good for everyone? American Journal of Clinical Nutrition, 87(3), 517-533.

Stevens, R., Buret, M., Garchery, C., Carretero, Y., \& Causse, M. (2006). Technique for rapid, smallscale analysis of vitamin $\mathrm{C}$ levels in fruit and application to a tomato mutant collection. Journal of Agricultural and Food Chemistry, 54(17), 6159-6165.

USDA. National nutrient database for standard reference, http://ndb.Nal.Usda.Gov, Accessed 21 July 2016 and 10 November 2018.

Verlinde, P. H. C. J., Oey, I., Lemmens, L., Deborggraeve, W. M., Hendrickx, M. E., \& Van Loey, A. M. (2010). Influence of reducing carbohydrates on (6S)-5-methyltetrahydrofolic acid degradation during thermal treatments. Journal of Agricultural and Food Chemistry, 58(10), 6190-6199. 
Figure 1 :

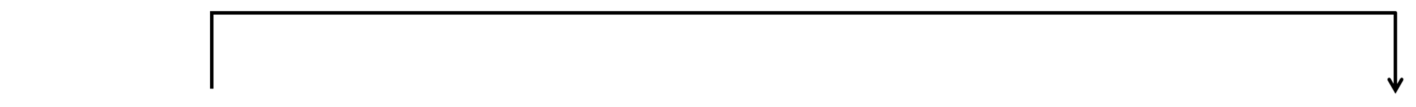<smiles>[R3]CC1CNc2nc(NC(C)C(=O)O)[nH]c(=O)c2N1C</smiles>

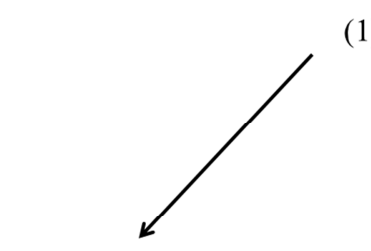

Unknown reaction products

(5)
(2)

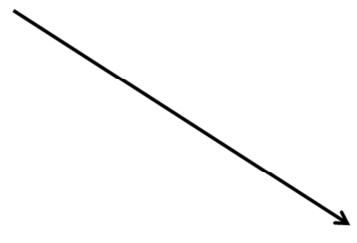

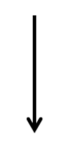

(4)

(6)

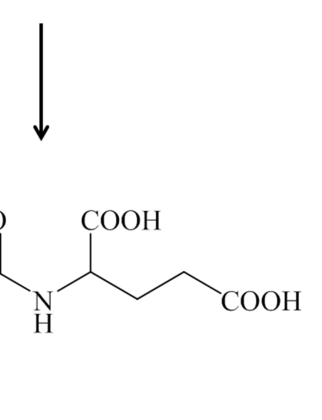

(3) 
Figure 2:
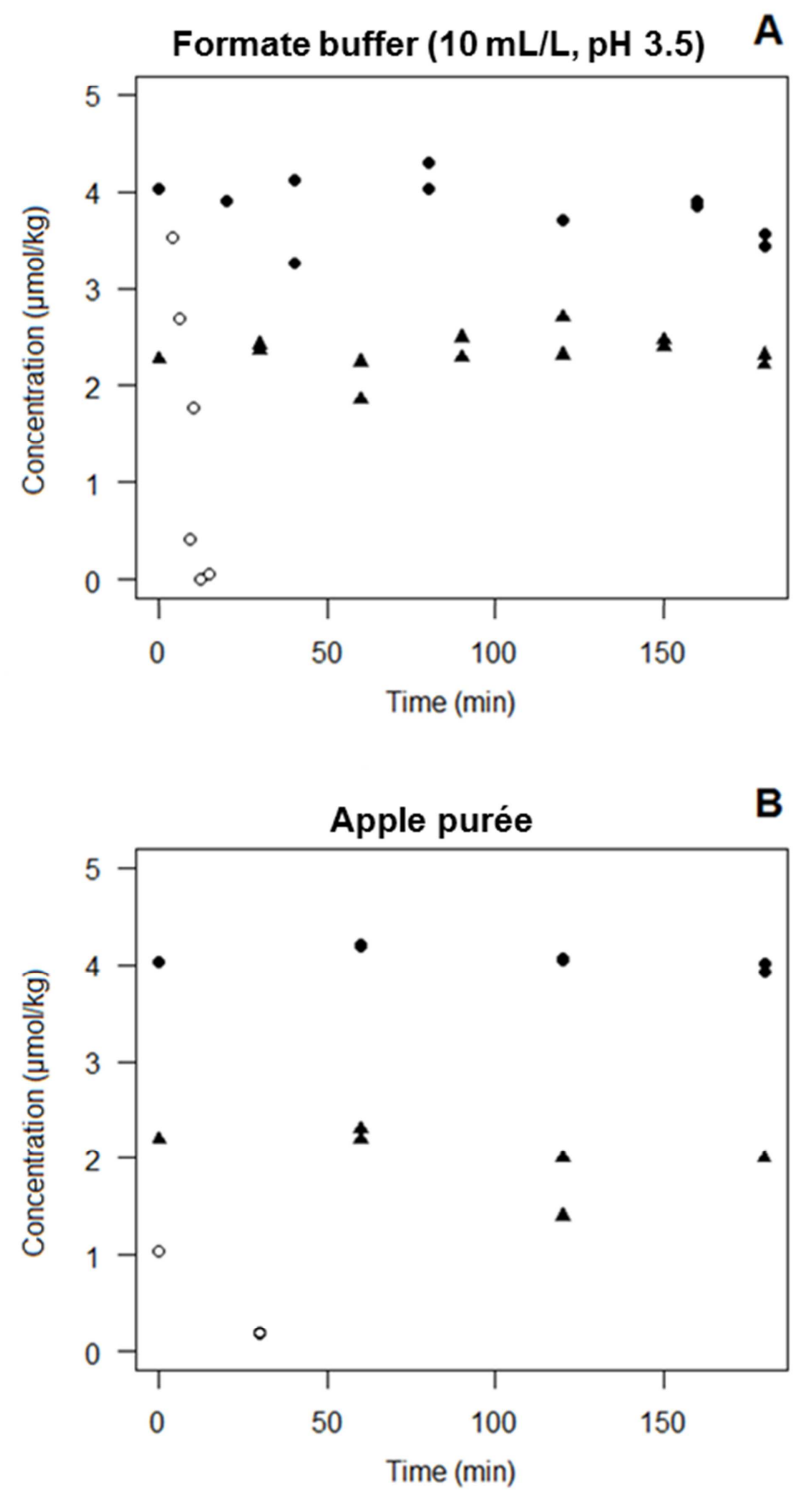
Figure 3:
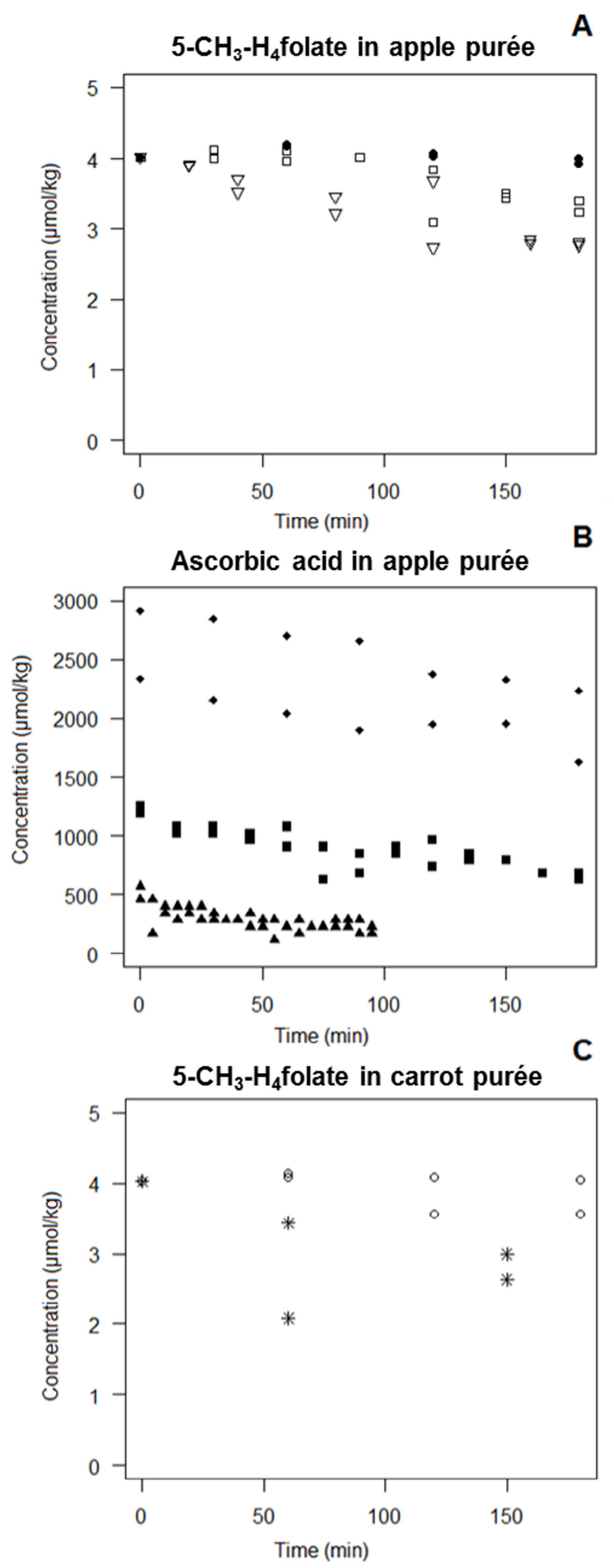
Figure 4:

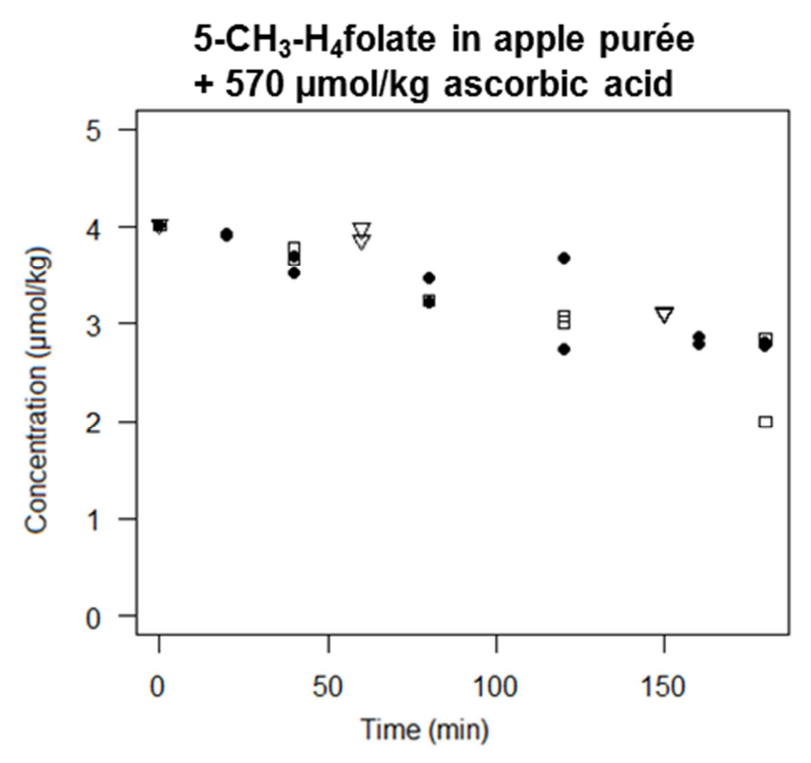

